\title{
Senile atrophy of the human lacrimal gland: the contribution of chronic inflammatory disease
}

\author{
B. E. DAMATO, ${ }^{\prime}$ D. ALlan,${ }^{2}$ S. B. MURRAY, ${ }^{\text {and }}$ W. R. LEE'
}

From the 'University Department of Ophthalmology, Glasgow G12 8QQ; and the ${ }^{2}$ West of Scotland Health Boards' Department of Clinical Physics and Bioengineering, Glasgow G4 9LF

SUMmARY Histological examination of 99 human lacrimal glands showed a relationship between atrophy of the secretory acini and secretory duct obstruction, ascending periductal fibrosis, and obliteration of the adjacent blood vessels caused by lymphocytic and polymorphonuclear inflammation. Investigation of the subgroups of the B lymphocytic series by immunohistochemistry did not show any statistical change with age, sex, fibrosis, or lymphocytic inflammation. The concept of senile atrophy occurring as a result of senescent involution of the lacrimal gland is challenged on the basis of the histological findings.

Keratoconjunctivitis sicca in the elderly population is widely considered to be due to senescent involution of the lacrimal gland. ${ }^{1-3}$ This degeneration has been termed 'senile atrophy' to distinguish the condition from atrophy secondary to Sjögren's syndrome, infection, and malignancy. Although arteriosclerosis ${ }^{45}$ and inflammation ${ }^{67}$ were formerly considered to be important causative factors, various clinical reports ${ }^{89}$ have recently stressed the need for further contemporary histological studies of age related changes in the lacrimal gland.

This study of the human lacrimal gland was carried out in order to define the nature and prevalence of fibrosis, acinar atrophy, and duct pathology. The original hypothesis was that, if a low intensity inflammatory process had caused these changes, there might be alterations in the relative frequency and distribution of the subgroups of the B lymphocytic series. Accordingly this component of the immune system was investigated by means of immunohistochemistry.

\section{Materials and methods}

Lacrimal gland tissue was obtained from two exenteration specimens and 97 post-mortem examinations of patients in a general hospital. Two-thirds of these specimens were used in a previous study. ${ }^{3}$ The patients were randomly selected, and cases were excluded from the study only if the quality or quantity

Correspondence to Dr B. E. Damato, Department of Ophthalmology, University of Glasgow, Glasgow G12 8QQ. of the material did not permit histological grading of the degree of fibrosis.

The lacrimal gland was removed from one or both sides within 24 hours post mortem either via the orbit or by the conjunctival route. The tissue was fixed in cacodylate gluteraldehyde $2.5 \%$ or buffered formalin and embedded in paraffin. Sections were stained with haematoxylin and eosin, and Unna-Pappenheim technique, and the immunoperoxidase technique for immunoglobulins and macrophages ${ }^{10}$ (Dakopatts $\mathrm{A} / \mathrm{S}$ ). Without prior knowledge of the age, sex, and cause of death the pathological material was categorised according to the degree of fibrosis, duct pathology, and acinar atrophy. When both glands had been removed, quantitative assessment was carried out on only one specimen, which was chosen at random. This was because prior examination had revealed no significant differences between the two sides.

The cases were further categorised according to the presence and type of inflammatory cell infiltrate. A quantitative assessment of the $\operatorname{IgA}, \operatorname{IgG}$, and $\operatorname{IgM}$ plasma cells was possible in only 35 cases. This was because the immunoperoxidase technique was sensitive to autolysis. Statistical analysis showed the age (Mann-Whitney test, $p>0.2)$ and $\operatorname{sex}\left(\chi^{2}\right.$ test, $\left.p>0.5\right)$ distributions of this sample to be representative of the whole group. Attempts at using the Optomax Image Analyser (Micromeasurements Ltd) for this quantitative analysis were unsuccessful because of interference by $\operatorname{IgA}$ in the acinar lumina and because the plasma cells tended to be closely clustered. These 
Table 1 Variation in the degree of fibrosis with age

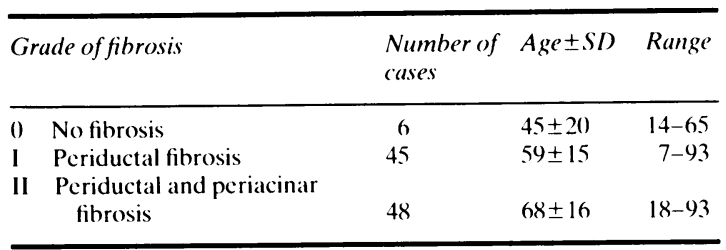

Analysis of variance, (1).(0)1<p<0).(01.

cells were therefore counted visually in 10 randomly selected high power fields $(\times 40$ objective $)$ by means of an eyepiece grid. Reproducibility studies were carried out on two cases chosen at random. These showed that the results of a second count, carried out on a separate occasion, were comparable (MannWhitney test, $p>0 \cdot 1)$. Although plasma cell counts were carried out on slides labelled with $1 / 400$ or $1 / 1600$ dilutions of horseradish peroxidase, depending on stain definition, no significant differences in the cell

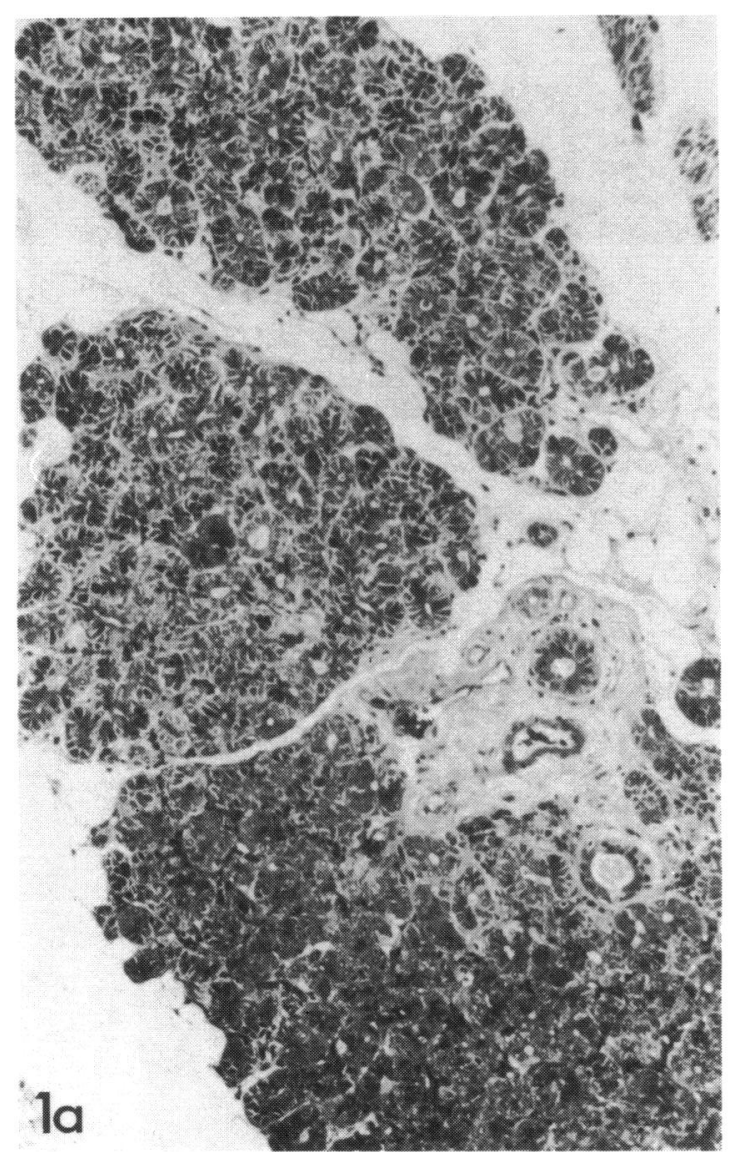

counts for the two dilutions were found (MannWhitney test, $p>0 \cdot 1$ for all plasma cell types).

\section{Results}

Lacrimal gland tissue from 99 cases was studied. The sample consisted of 52 males and 47 females with a mean age of 62 years ( $\mathrm{SD} \pm 17$ years) ranging from 7 to 93 years. There was no significant difference between the ages of male and female patients (MannWhitney test, $p>0 \cdot 2$ ).

\section{FIBROSIS}

Fibrosis was totally absent in six specimens (Table 1). It was classified as grade 1 if it was present only in the periductal regions (Fig. 1a) or grade 2 if it was present in the periductal and periacinar regions (Fig. 1b). This classification differs from that previously reported. ${ }^{3}$ Most of the cases showed a variation in the degree of fibrosis between lobules. These were graded according to the most severe changes present. Actual

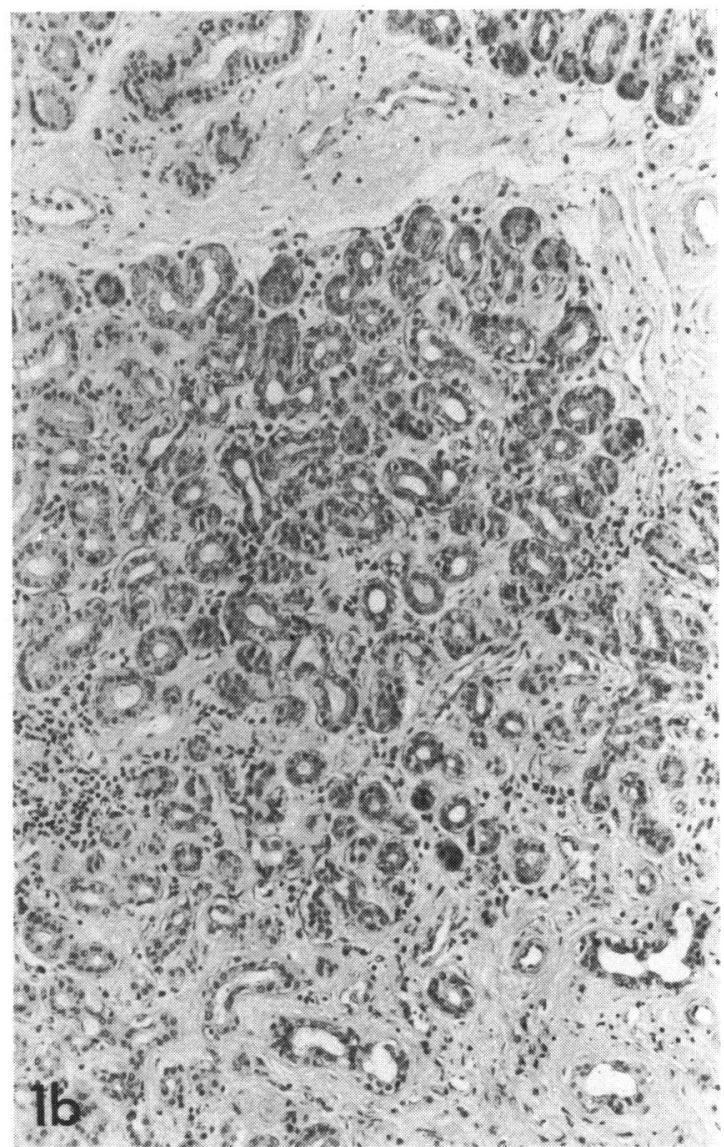

Fig. 1a Grade I fibrosis surrounds the secretory ducts but not the acini. (Hand E, $\times 99$ ). 1b: Grade II fibrosis surrounds the secretory ducts and acini. Most of these acini are atrophic. (H and E, $\times 112)$. 

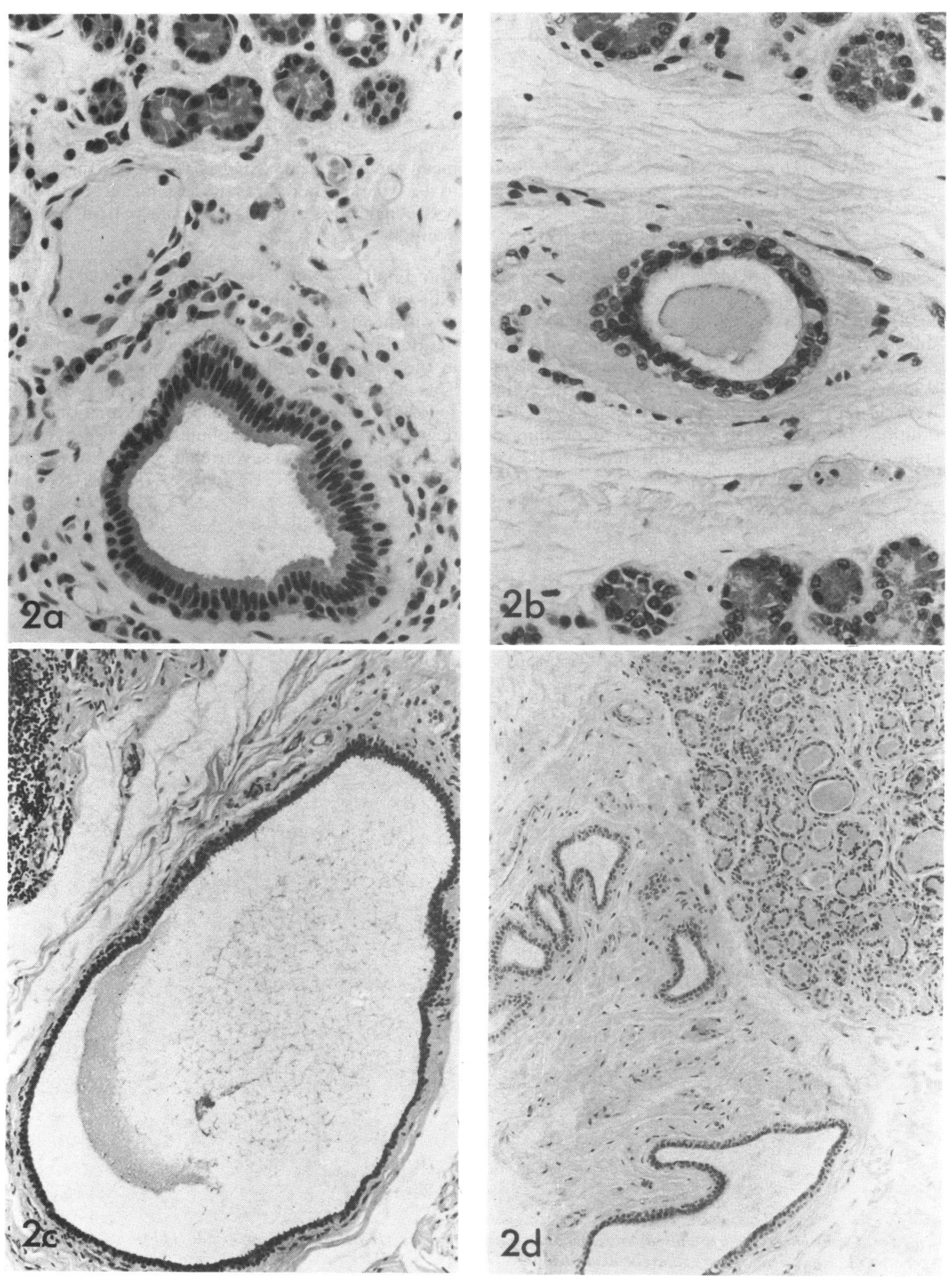
Table 2 Variation in the degree of duct pathology with age

\begin{tabular}{|c|c|c|c|c|}
\hline \multicolumn{2}{|c|}{ Grade of duct pathology } & \multirow{2}{*}{$\begin{array}{l}\begin{array}{l}\text { Number of } \\
\text { cases }\end{array} \\
11\end{array}$} & \multirow{2}{*}{$\begin{array}{l}A g e \pm S D \\
40 \pm 21\end{array}$} & \multirow{2}{*}{$\begin{array}{r}\text { Range } \\
\frac{7-65}{}\end{array}$} \\
\hline 0 & All ducts normal & & & \\
\hline I & Less than $50 \%$ ducts abnormal & 35 & $62 \pm 12$ & $38-93$ \\
\hline II & $\begin{array}{l}\text { More than } 50 \% \text { ducts } \\
\text { abnormal }\end{array}$ & 33 & $64 \pm 14$ & $30-91$ \\
\hline III & All ducts abnormal & 16 & $72 \pm 16$ & $18-89$ \\
\hline IV & Uncertain & 4 & & \\
\hline
\end{tabular}

Analysis of variance, $\mathrm{p}<0 \cdot(001$.

replacement of the glandular structures by fibrous tissue was extremely rare.

Fibrosis tended to be more extensive in the later decades (analysis of variance, $0 \cdot 001<p<0 \cdot 01$ ). No significant sex bias was noted $\left(\chi^{2}\right.$ test, $\left.0 \cdot 1<\mathrm{p}<0 \cdot 5\right)$.

\section{DUCT PATHOLOGY}

Normal secretory ducts were straight and narrow, and surrounded by loose areolar tissue. They were lined by a bilayered epithelium formed internally by long columnar cells and externally by cuboidal myoepithelial cells (Fig. 2a). A number of small blood vessels, which will be referred to as paraductal vessels, appeared to run parallel to the ducts from the conjunctiva to the lacrimal glands.

Abnormal ducts were dilated and tortuous (Figs. $2 \mathrm{~b}$ and $2 \mathrm{~d}$ ) and lined by an atrophic epithelium composed of low columnar or cuboidal cells (Fig. $2 b)$. The paraductal vessels seemed to be less numerous around these ducts (Fig. $2 b$ ), which were often surrounded by much fibrous tissue.

The patients with more severe duct pathology tended to be older (Table 2 , analysis of variance, $\mathrm{p}<0.001)$. There was no significant sex bias $\left(\chi^{2}\right.$ test, $\mathrm{p}>0 \cdot 5)$. The presence of duct changes correlated with fibrosis (Fisher's exact probability test, $\mathrm{p}<0 \cdot 001$ ).

Cyst formation, which represents the most severe duct pathology (Fig. 2c), occurred in 19 cases. This group was significantly older than those without cyst formation (Mann-Whitney test, $0 \cdot 001<\mathrm{p}<0 \cdot 01$ ).

\section{ATROPHY}

Normal acini were lined by long columnar cells filled with secretory granules; in atrophic acini the epithelium was low columnar or cuboidal, with scanty secretory granules. These atrophic acini tended to have a wide lumen, which was filled with inspissated secretions in some cases (Fig. 2d). In most glands there was a distinct variation in the degree of atrophy
Table 3 Variation in the degree of atrophy with age

\begin{tabular}{|c|c|c|c|c|}
\hline \multicolumn{2}{|c|}{ Grade of atrophy } & \multirow{2}{*}{$\begin{array}{l}\text { Number of } \\
\text { cases }\end{array}$} & \multirow{2}{*}{$\begin{array}{l}A g e \pm S D \\
45 \pm 21\end{array}$} & \multirow{2}{*}{$\begin{array}{r}\text { Range } \\
7-67\end{array}$} \\
\hline 0 & No atrophy & & & \\
\hline I & Less than $50 \%$ acini atrophic & 40 & $61 \pm 12$ & $30-84$ \\
\hline II & More than $50 \%$ acini atrophic & 26 & $70 \pm 11$ & $44-91$ \\
\hline III & All acini atrophic & 11 & $68 \pm 19$ & $18-89$ \\
\hline IV & Uncertain & 8 & & \\
\hline
\end{tabular}

Analysis of variance, $\mathrm{p}<0 \cdot()(0) 1$

between lobules or between lobular segments. When the size of the lobules had diminished as a result of atrophy the interlobular areas were filled by fat cells.

Analysis of variance showed the degree of acinar atrophy to be greater in specimens from older individuals (Table $3, \mathrm{p}<0 \cdot 001$ ). No significant sex bias was present $\left(\chi^{2}\right.$ test, $\left.0 \cdot 1<p<0 \cdot 5\right)$. Acinar atrophy correlated significantly with the grade of fibrosis $(p<0.001)$ and with the severity of duct pathology $(p<0.001)$ when tested by Fisher's exact probability test.

\section{INFLAMMATORY CELL INFILTRATION}

Seventy out of 99 lacrimal glands showed lymphocytic infiltrates, which were usually situated near the secretory ducts in the hilar regions of the lobules or in the interlobular regions. The lymphocytes tended to form aggregates around the paraductal vessels (Fig. 3a) rather than around the ducts themselves.

A significant relationship was found between lymphocytic infiltration and the presence of fibrosis (Fisher's exact probability test, $\mathrm{p}<0 \cdot 001$ ), duct pathology $\left(\chi^{2}\right.$ test, $\left.p<0.001\right)$ and acinar atrophy $\left(\chi^{2}\right.$ test, $\mathrm{p}<0 \cdot 001)$ (Table 4).

In 10 cases a polymorphonuclear cell infiltrate was present, which tended to be most marked near the secretory ducts (Fig. 3b).

Plasma cells were situated in the interacinar spaces and around the secretory ducts. The mean numbers of plasma cells per unit area $\left(0.09 \mathrm{~mm}^{2}\right)$ are shown in Table 5. None of the plasma cell populations showed significant variation with age (correlation coefficient, $p>0 \cdot 1$ ), sex (Mann-Whitney test, $p>0 \cdot 5$ ), grade of fibrosis (analysis of variance, $p>0 \cdot 1$ ), or lymphocytic infiltration (analysis of variance, $p>0 \cdot 2$ ). However, for females only, evaluation of the correlation coefficient demonstrated a significant relationship between IgG and IgA $(0.001<p<0.01)$ and IgG and $\operatorname{IgM}(0 \cdot 02<\mathrm{p}<0 \cdot 05)$.

Fig. 2a A normal secretory duct is lined by columnar cells and surrounded by plasma cells and blood vessels. ( $H$ and $E$, $\times 260)$. 2b: An abnormal secretory duct is lined by flattened epithelial cells and surrounded by fibrous tissue in which few blood vessels are present. (Hand $E, \times 267)$. 2c: Cystic dilatation of a secretory duct. (Hand $E, \times 104)$. $2 \mathrm{~d}$ : The secretory ducts are dilated and tortuous. The acini are filled with retained secretions and lined by an atrophic epithelium. $(H$ and $E, \times 107)$. 

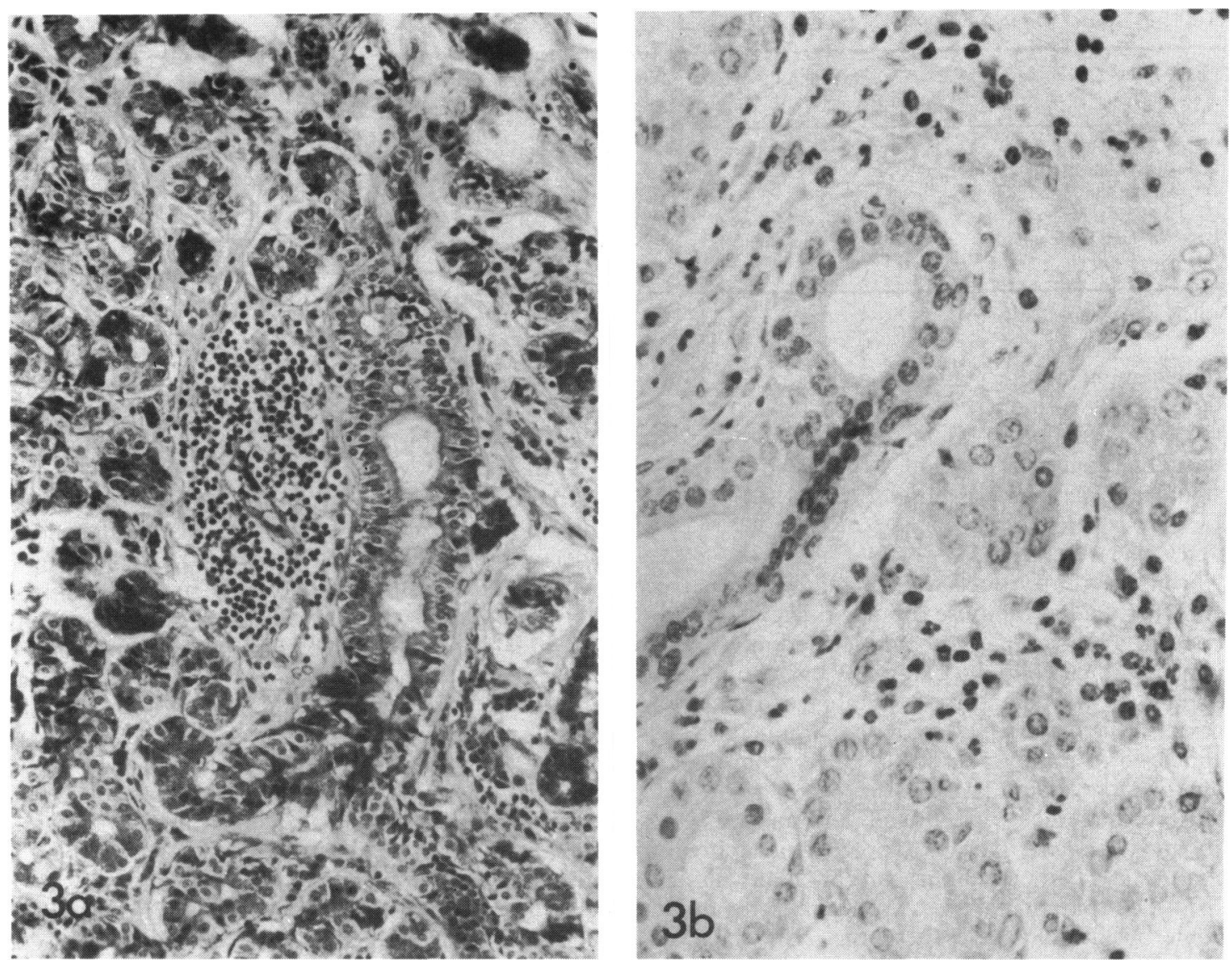

Fig. 3a A lymphocytic aggregate formed around a paraductal vessel. (Hand $E, \times 260)$. $3 \mathrm{~b}$ : A polymorphonuclear and lymphocytic infiltrate in the region of a secretory duct. ( $H$ and $E, \times 427)$.

\section{Discussion}

Although acinar atrophy and fibrosis occurred more extensively in the later decades, the same changes were also noted in younger patients. This suggests that the atrophy starts before middle age in parallel with the gradual decline in tear production that is known to begin in early adult life. ${ }^{11} 12$ Such findings are not consistent with the prevailing opinion that senile keratoconjunctivitis sicca is due to senescent atrophy of the lacrimal gland.
The interlobular variation in the degree of acinar atrophy suggests that this is due to a pathological process in the hilar region of each lobule. In this region dilatation and tortuosity of the secretory ducts, occasionally culminating in cyst formation, suggest that a degree of obstruction may be present. ${ }^{13}$ This obstruction could account for atrophy of the secretory acini.

Another potential destructive component might be ischaemia secondary to a low grade vasculitis in the paraductal vessels. Further study of the normal and

Table 4 Relationship between presence of lymphocytic infiltration, and fibrosis, duct pathology, and atrophy

\begin{tabular}{|c|c|c|c|c|c|c|}
\hline \multirow{2}{*}{$\begin{array}{l}\text { Lymphocytic } \\
\text { infiltration }\end{array}$} & \multicolumn{2}{|l|}{ Fibrosis } & \multicolumn{2}{|c|}{ Duct pathology } & \multicolumn{2}{|c|}{ Atrophy } \\
\hline & Absent & Present & Absent & Present & Absent & Present \\
\hline Absent & 6 & 23 & 8 & 19 & 11 & 17 \\
\hline Present & 0 & 70 & 3 & 65 & 3 & 60 \\
\hline Total studied & \multicolumn{2}{|c|}{99} & \multicolumn{2}{|c|}{95} & \multicolumn{2}{|c|}{$91^{00}$} \\
\hline
\end{tabular}


Table 5 Average number of plasma cells per unit area

\begin{tabular}{llcccc}
\hline $\begin{array}{l}\text { Plasma cell } \\
\text { type }\end{array}$ & $\begin{array}{l}\text { Number of } \\
\text { glands studied }\end{array}$ & \multicolumn{4}{l}{$\begin{array}{l}\text { Number of plasma cells per unit } \\
\text { area }\left(0.09 \mathrm{~mm}^{2}\right)\end{array}$} \\
\cline { 2 - 6 } & & Mean & Max. & Min. & SD \\
\hline IgA & 33 & 29 & 51 & $7 \cdot 6$ & 11 \\
IgM & 34 & $1 \cdot 8$ & 23 & $0 \cdot 0$ & $4 \cdot 0$ \\
IgG & 28 & $1 \cdot 3$ & $4 \cdot 5$ & $0 \cdot 1$ & $1 \cdot 1$ \\
\hline
\end{tabular}

pathological anatomy of the vascular bed of the gland is required to prove this hypothesis.

Our findings that interacinar and periductal fibrosis tends to occur later in life than periductal fibrosis alone would suggest that fibrosis initially develops around the secretory ducts and gradually extends proximally into the lacrimal lobules.

It has been suggested that the lymphocytic infiltration in the lacrimal gland forms part of the normal conjunctiva-associated lymphoid tissue (CALT) described recently by Axelrod and Chandler. ${ }^{14}$ However, the finding in the present study that lymphocytic infiltrates were absent in almost one-third of the specimens suggests that these are pathological in nature. Other authors studying the post-mortem prevalence of focal lymphocytic adenitis of the submandibular gland have reached similar conclusions. ${ }^{15}$ The statistical and histological findings of our study suggest that lymphocytic infiltration in the lacrimal gland is related to fibrosis in a manner similar to other chronic inflammatory diseases. Recent studies have shown that lymphocytes and macrophages can release factors which induce fibroblastic activity and hence tissue fibrosis ${ }^{16}$ and vascular obliteration. ${ }^{17}$ It is noteworthy that many fibrotic glands were free from lymphocytic infiltration. This could be due to the intermittent nature of the process.

The lymphocytic aggregates could represent a low grade dacryoadenitis secondary to systemic infections ${ }^{18-20}$ or conjunctivitis. ${ }^{21}$ The latter could be due to nasolacrimal duct obstruction, 22 exposure, immunodeficiency states, ${ }^{2.3}$ or could even be a selfpropagating disease state in a tear-deficient patient.

The histological appearances are also similar to the less severe grades of Sjögren's syndrome. ${ }^{\times 2+}$ However, other authors have dismissed autoimmunity as a cause of senile keratoconjunctivitis sicca, because patients suffering from this disease do not show an increased incidence of autoantibodies. 'In Sjögren's syndrome, when immunological aberrations ${ }^{25}$ occur as a result of a genetic predisposition, ${ }^{20}$ these autoantibodies are considered to be an epiphenomenon. ${ }^{27}$ It is possible that similar hypersensitivity phenomena occurring as a result of systemic disease ${ }^{28}$ could cause similar histological appearances. Conditions like Reiter's syndrome, acne rosacea, and inflammatory bowel disease, ${ }^{29}$ which cause episcleritis and conjunctivitis would also be expected to affect the lacrimal gland, which is an extension of the conjunctiva.

Some of these conditions could also be responsible for the focal lymphocytic adenitis seen in other exocrine glands ${ }^{15.30}$ and may account for a significant proportion of middle aged patients with keratoconjunctivitis sicca unrelated to Sjögren's syndrome. ${ }^{31}$

The numbers of the different plasma cell types correspond closely to previously reported data. ${ }^{32}$ No age-related change in the distribution of the subgroups in the plasma cell populations could be demonstrated. Previous reports ${ }^{33.34}$ of a gradual increase in tear $\operatorname{IgA}$ concentration with age could be indicative of diminished tear production. ${ }^{34}$

In conclusion, this study suggests that repeated episodes of subclinical dacryoadenitis occur throughout life to cause obstruction of the secretory ducts. This process may make a significant contribution to senile keratoconjunctivitis sicca by depleting the functional reserves of the main and accessory lacrimal glands.

Recognition of local and systemic causes of subclinical dacryoadenitis may enable keratoconjunctivitis sicca to be prevented or delayed by appropriate therapy.

We thank Mr J. A. Ralston and Mr J. A. Stewart for the histological preparation of specimens; Mr R. J. McNeil for obtaining postmortem material; Mrs D. Aitken for the illustrations, and Mrs J. Murray for secretarial help.

This study was supported by a grant from the Ross Foundation for the Prevention of Blindness, Edinburgh.

\section{References}

1 Duke-Elder S. The ocular adnexa. System of ophthalmology. London: Kimpton, 1974: 13: 625-6.

2 Whalcy K, Williamson J, Wilson T, et al. Sjögren`s syndrome and autoimmunity in a geriatric population. Age and Ageing 1972; 1: 197-206.

3 Murray SB, Lee WR. Williamson J. Ageing changes in the human lacrimal gland: a histological study. J (lin Exp Gerontology 1981: 3: 1-27

4 Buchaly JF. Ucher dic pathohistologic der Tränendrüsen in Abhängigkeit von lebensalter und Gesamtorganismus. Zentralb/ Allg Pathol 1933; 58: 58-69.

5 Radnót M. Die pathologische Histologie der Tränendrusé. Bascl: Karger, 1939.

6 Radnót M. Szabo Z. Beiträg zur pathologischen Histologic der Tränendrusc. Vorkommen von Mastzellen in der Träinendruse. Acta Chir Acad Sci Hung 1966; 7: 55-62.

7 Herken H. Beiträg zur pathologischen Histologic der Trändendrüsc. Arch Augenheilkd 1937; 110: 61-75.

8 Williamson J, Gibson AAM, Wilson T, et al. Histology of the lacrimal gland in keratoconjunctivitis sicca. $\mathrm{Br} J \mathrm{Ophthalmol}$ 1973; 57: 852-8.

9 Brown SI. Clinical dry cyc states. In: Suran A, Gery I, Nussenblatt RB, cds. Immunology of the eye. Workshop III. Special Suppl Immunology abstracts. 1981: 151-5.

10 Burns J, Hambridge M. Taylor CR. Intracellular immunoglobulins, a comparative study on three standard tissuc processing methods using horseradish peroxidase and fluorochrome conjugates. J Clin Pathol 1974: 27: 548-57. 
11 De Roetth A. On the hypofunction of the lacrimal gland. Am J Ophthalmol 1941; 24: 20-5.

12 Norn MS. Tear secretion in normal cyes. Acta Ophthalmol (Kbh) $1965 ; 43$ : 567-73.

13 Sourdille G. Les tumeurs kystiques bénignes de la glande lacrymale (dacryops). Bull Soc Ophthalmol Fr 1899; 17: 244-55.

14 Axelrod AJ, Chandler JW. Morphologic characteristics of conjunctival lymphoid tissue in the rabbit. In: Silverstein AM, O'Connor GR, eds. Immunology and immunopathology of the eye. New York: Masson, 1979: 292-301.

15 Waterhouse JP, Doniach I. Post-mortem prevalence of focal lymphocytic adenitis of the submandibular salivary gland. $J$ Pathol Bacteriol 1966; 91: 53-64.

16 Wahl LM, Wahl SM. Regulation of connective tissue metabolism by the immune system. In: Suram A, Gery I, Nussenblatt RB, eds. Immunology of the eye. Workshop III. Special Suppl Immunology Abstracts. 1981: 291-301.

17 Parish WE. Microbial antigens in vasculitis. In: Wolff $\mathbf{K}$, Winkelmann RK, eds. Vasculitis. London: Lloyd-Luke, 1980: 129-50.

18 Wilson P. Acute unilateral dacryoadenitis. A report of four patients. Br Med J 1951; i: 1183-5.

19 Richardson JM. Acute metastatic gonococcal dacryoadenitis: a clinical and histologic study. Arch Ophthalmol 1942; 28: 93-133.

20 Jones BR. Lacrimal disease associated with infectious mononucleosis. Trans Ophthalmol Soc UK 1955; 75: 101-19.

21 Jones BR. The clinical features and aetiology of dacryoadenitis. Trans Ophthalmol Soc UK 1955; 75: 435-52.

22 Beigelman MN. Pathology of the lacrimal glands in chronic epiphora. Am J Ophthalmol 1928; 11: 125-8.

23 Freidlander MH, Masi RJ, Osumoto M, Smolin G, Ammann AJ. Ocular microbial flora in immunodeficient patients. Arch Ophthalmol 1980; 98: 1211-3.
24 Bloch KJ, Buchanan WW, Wohl MJ, Bunim JJ. Sjögren's syndrome: a clinical, pathological and serological study of 62 cases. Medicine (Baltimore) 1965; 44: 187-231.

25 Moutsopoulos HM, Fauci AS. Immunoregulation in Sjögren's syndrome. Influence of serum factors on T-cell subpopulations. $J$ Clin Invest 1980; 65: 519-28.

26 Moutsopoulos HM, Mann DL, Johnson AH, Chused TM. Genetic differences between primary and secondary sicca syndrome. N Engl J Med 1979; 301: 761-3.

27 Whaley K, Chisholm DM, Goudie RB, et al. Salivary duct autoantibody in Sjögren's syndrome: correlation with focal sialadenitis in the labial mucosa. Clin Exp Immunol 1969; 4: 27382.

28 Stiller CR, Russell AS, Dossetor JB. Autoimmunity: present concepts. Ann Intern Med 1975; 82: 405-10.

29 Wright $P$. Conjunctival changes associated with inflammatory disease of the bowel. Trans Ophthalmol Soc UK 1980; 100: 96-7.

30 Chisholm DM, Waterhouse JP, Mason DK. Lymphocytic sialadenitis in the major and minor glands: a correlation in postmortem subjects. J Clin Pathol 1970; 23: 690-4.

31 Forstot JZ, Forstot SL, Greer RO, Tan EM. The incidence of Sjögren's sicca complex in a population of patients with keratoconjunctivitis sicca. Arthritis Rheum 1982; 25: 156-60.

32 Franklin RM, Kenyon KR, Tomasi TB Jr. Immunohistologic studies of human lacrimal gland: localization of immunoglobulins, secretory component and lactoferrin. J Immunol 1973; 110: 984 92.

33 Sen DK, Sarin GS, Mathur GP, Saha K. Biological variation of immunoglobulin concentrations in normal human tears related to age and sex. Acta Ophthalmol (Kbh) 1978; 56: 439-44.

34 Harada M, Miyata M, Ishikawa S. Antibacterial substances in human tears. Jpn J Ophthalmol 1980; 24: 320-7. 